\section{Fertilization Program and Resin Foam Soil Amendment Effects on Sod Establishment}

\author{
Panayiotis A. Nektarios, ${ }^{1}$ Georgios Tsoggarakis, ${ }^{2}$ Aimilia-Eleni \\ Nikolopoulou, ${ }^{3}$ and Dimitrios Gourlias ${ }^{2}$ \\ Agricultural University of Athens, Department of Floriculture and Landscape \\ Architecture, 75, Iera Odos, 118 55, Athens, Greece
}

Additional index words. urea formaldehyde, quick release fertilizer, slow release fertilizer, foliar fertilizer, vertical detachment force, sod anchorage

\begin{abstract}
Two field studies (winter and summer) were performed to evaluate the effect of three different fertilizer programs and a urea formaldehyde resin foam (UFRF) soil amendment on sod establishment and anchorage. Fertilizer treatments involved were 1) a quick release (QR) granular fertilizer (12-12-17); 2) a slow release (SR) fertilizer (27-5-7); and 3) a foliar

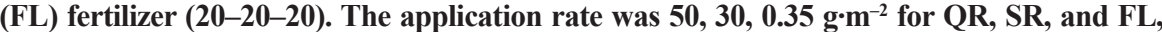
respectively. The substrate consisted of sandy loam soil, and in half of the plots UFRF flakes were incorporated in the upper $100 \mathrm{~mm}$ at a rate of $20 \% \mathrm{v} / \mathrm{v}$. The effects of the fertilizer and soil amendment on sod establishment were evaluated through measurements of the dry weight of clippings and roots and the visual quality of the turf. Sod anchorage was measured by determination of the vertical force required to detach a piece of sod. For each treatment the initial and final pH, EC, available $\mathrm{P}$, exchangeable $\mathrm{K}, \mathrm{Ca}, \mathrm{Mg}$, and $\mathrm{Fe}$ were also determined. It was found that FL reduced clipping yield but retained turf visual quality similar to the other fertilizer treatments except in winter, when it resulted in the worst quality ratings. However, FL fertilizer promoted root growth and provided high vertical detachment force values and therefore enhanced sod establishment. Slow release fertilizer resulted in moderate top growth and visual quality of the turf during winter, but delayed sod establishment. Quick release fertilizer increased top growth and improved turfgrass visual quality during the winter, but root growth and vertical detachment force were reduced, indicating poorer sod establishment. UFRF did not enhance sod establishment since there was a negative effect on root growth when temperatures were below $10^{\circ} \mathrm{C}$, without however affecting vertical detachment force. Differences in soil $\mathrm{P}, \mathrm{K}, \mathrm{Ca}, \mathrm{Mg}$ and $\mathrm{Fe}$ between treatments were inconsistent between the two studies, except for final $K$ concentration, which was higher for QR fertilization than SR and FL. Foliar fertilization can enhance sod establishment compared to QR and SR, by accelerating sod anchorage and root growth. QR can be used in late autumn to improve winter green up of the sod. UFRF does not improve or accelerate sod establishment and possesses a minimal capacity to improve soil properties of sandy loam soils.
\end{abstract}

Optimization of sod establishment methodology is of major importance since in most cases sodding is the preferred method of turfgrass establishment technique when time is a limiting factor or there is a need for rapid establishment to reduce erosion. Successful sodding is highly correlated with root growth and intrusion into the underlying substrate, while the rate of establishment is related to the time needed for the roots to provide anchorage of the sod to the substrate.

Sod transplanting success and anchorage efficiency is governed by several factors including soil texture, soil moisture and fertilization. Peacock and Dudeck (1985) found that st. augustine [Stenotaphrum secundatum (Walt.) Kuntze.] sod transplanted to loamy fine sand exhibited greater rooting strength than sod grown on organic soil, while King and Beard

Received for publication 18 Mar. 2004. Accepted for publication 10 June 2004. The authors want to thank Harold Passam for his help on reviewing and improving the manuscript.

${ }^{1}$ Assistant professor.

${ }^{2}$ Graduate research assistant.

${ }^{3} \mathrm{PhD}$ candidate.
(1969) reported similar vertical force values for 'Merion'kentucky bluegrass (Poapratensis L.) sod grown on organic and loamy soils. Dunn and Engel(1970) recorded higher shear strength values for kentucky bluegrass sod grown on a mineral soil than on organic soils and Schmidt et al. (1986) reported that less vertical pull was required for kentucky bluegrass sod grown on a sandy compared to a loamy soil. King and Beard (1972), reported that laying sod on a moist surface enhanced root growth compared with sod transplanted onto dry soil.

Soil amendments improve turfgrass growth and have the potential to enhance sod establishment by altering the substrate's physical and chemical properties as well as the moisture and nutrient holding capacity. Urea-formaldehyde resin foam (UFRF) is a synthetic organic soil amendment that has recently been used for turfgrasses(Mooney and Baker, 1999; Nektarios et al., 2003). UFRF is a porous material with a water holding capacity of up to $60 \%(\mathrm{v} / \mathrm{v})$; it is lightweight (18 to $30 \mathrm{~kg} \cdot \mathrm{m}^{-3}$ ) and biodegradable over a period of 10 years (Baader, 1999). Even though the N percentage of UFRF varies from $30 \%$ to $38 \%$, the soluble part is restricted to only $0.3 \%$ (Werminghausen, 1972). UFRF is expected to release about $6 \mathrm{~g} \cdot \mathrm{m}^{-2}$ of N/year when the incorporation rate is $20 \% \mathrm{v} / \mathrm{v}$ (Baader, 1999). Mooney and Baker (1999) tested different proportions of UFRF $(0 \%, 7.5 \%, 15 \%$, $22.5 \%$ and $30 \% \mathrm{v} / \mathrm{v}$ ) in pure sand, sand mixed with peat $(80: 20)$, and sand mixed with sandy loam soil $(80: 20)$, to evaluate the impact of UFRF on soil physical properties with respect to the guidelines of the U.S. Golf Association. These authors found a positive effect of UFRF on the golf green rootzones tested. The main benefit of UFRF was increased water retention and the researchers concluded that for sand-soil golf rootzone mixes the incorporation of $7.5 \%$ and $15 \%$ UFRF was fully consistent with the specifications.

In addition to substrate improvement, fertilization programs may enhance establishment of sod rooting and anchorage by optimising either the release properties or absorption pathways of the different nutrients. Fertilizer placement at the sod surface, rather than at the interface between the sod and substrate, provided better rooting strength of St. Augustine sod (Peacock and Dudeck, 1985). However, in kentucky bluegrass sod, incorporation of the fertilizer into the substrate did not increase root production, compared to placement at the sod surface (King andBeard, 1972). Increasing $\mathrm{N}$ application from 5 to $10 \mathrm{~g} \cdot \mathrm{m}^{-2}$ reduced the rooting strength of st. augustine sod (Peacock and Dudeck, 1985). In contrast, the increase of $\mathrm{N}$ fertilization from 2.5 to $10 \mathrm{~g} \cdot \mathrm{m}^{-2}$ in Tifgreen bermudagrass (Cynodon dactylon $\times C$. transvaalensis) provided more root weight at a depth of 0 to $100 \mathrm{~mm}$ during the first year (Snyder and Cisar, 2000). Rodriguez et al. (2001), reported that several N-P-K ratios affected shoot growth in bermudagrass cultivars, but not root growth. Sufficient N application during sod production had a positive carry on effect on visual quality and clipping yield after transplanting (Cisar et al., 1992).

The sod industry uses various types of fertilizers during sod establishment. QR fertilizers are used because they are inexpensive, SR fertilizers because they minimize traffic and foot printing over the wet areas of newly established sod, and FL fertilizers because empirical observations have indicated better rooting. Therefore the objective of the present study is 1) to evaluate the impact of UFRF amendment on the establishment and anchorage of the sod, and 2) to compare the impact of three different fertilizer schedules to enhance sod anchorage and establishment.

\section{Materials and Methods}

Two field studies were conducted at the Agricultural University of Athens, Greece. Study I was initiated on 15 Oct. 2001 and lasted until 3 Feb. 2002. It occupied a total area of $144 \mathrm{~m}^{2}$ and comprised 36 plots of $2 \times 2$ m each. Study II was performed at the same experimental site, but recorded sod establishment during the summer months from 22 June until 29 Sept. 2002.

The experimental field was drained by a 100 $\mathrm{mm}$, uniform, gravel layer incorporating three drainage trenches with $50 \mathrm{~mm}$ perforated pipes. The substrate was filled above the drainage layer at a depth of $300 \mathrm{~mm}$. Half of the plots were 
filled with a sandy loam soil (Entisols, Orthent; Theoharopoulos, 1992) having 78.8\% sand, $8.0 \%$ silt, $13.2 \%$ clay, $0.168 \mathrm{w} / \mathrm{w}$ organic matter, and a CEC of $6.23 \mathrm{cmol} \cdot \mathrm{kg}^{-1}$, which served as the control. The remaining plots were filled with the same sandy loam soil amended with UFRF (Fytofoam, Fytofoam Hellas LTD, Athens, Greece) in the form of flakes. The flakes had a bulk density of $18 \mathrm{~kg} \cdot \mathrm{m}^{-3}$ and were incorporated into the upper $100 \mathrm{~mm}$ of the soil profile at a rate of $20 \%(\mathrm{v} / \mathrm{v})$. After UFRF incorporation the experimental plots were sodded with a mixture that included tall fescue (Festuca arundinacea 'Houndog'), kentuckybluegrass (Poapratensis 'Emprima'), perennial ryegrass (Lolium perenne 'Chagall'), red fescue (Festuca rubra 'Herald'), and hard fescue (Festuca ovina 'Nordic') in a proportion of $40 \%, 30 \%, 15 \%, 10 \%$, and $5 \%$ (w/w), respectively. Each experimental plot was isolated from the adjacent plots and surrounding area by PVC sheets, to prevent mechanical and hydrological continuity.

In both studies, a starter granular fertilizer $(9.6 \mathrm{~N}-11.9 \mathrm{P}-12.5 \mathrm{~K})$ was incorporated into the substrates at a rate of $50 \mathrm{~g} \cdot \mathrm{m}^{-2}$. Fertilizer programs included 1) QR granular fertilizer (Complesal 12-12-17, having 6.5\% $\mathrm{NH}_{4}^{+}-\mathrm{N}$ and $5.5 \% \mathrm{NO}_{3}^{-}-\mathrm{N} ; 6.3 \mathrm{~N}-5.2 \mathrm{P}-14.1 \mathrm{~K}-1.2 \mathrm{Mg}-8 \mathrm{~S}$; Agrevo Hellas S.A., Athens, Greece), 2) SR fertilizer(Olympia 27-5-7,27N-2.18P-5.8K$1.8 \mathrm{Mg}-0.8 \mathrm{Fe}-0.4 \mathrm{Mn}$; Eurogreen-Wolf-Garten GmbH \& Co KG, An der Haselmauer 3, D56472 Nisterau) with $27.0 \%$ total $\mathrm{N}$ consisting of $1.1 \% \mathrm{NH}_{4}^{+}-\mathrm{N}, 8.3 \%$ urea-N and $17.6 \%$ slow release Poly Plus-N. Of the total N, 58.5\% was controlled release nitrogen $(\mathrm{CRN})$ and the size of the granules varied from 0.8 to 1.6 $\mathrm{mm}, 3$ ) FL fertilizer (Nutrileaf 60, 20-20-20; $20 \mathrm{~N}-11.27 \mathrm{P}-16.6 \mathrm{~K}-0.025 \mathrm{Mg}-0.05 \mathrm{Cu}-0.1 \mathrm{Fe}-$ $0.05 \mathrm{Mn}-0.05 \mathrm{Zn}-0.0005 \mathrm{Mo}-0.02 \mathrm{~B}$; Miller Chemical \& Fertilizer Corp., Hanover, PA). Of total $\mathrm{N}, 5.2 \%$ was $\mathrm{NH}_{4}^{+}-\mathrm{N}, 6.0 \% \mathrm{NO}_{3}^{-}-\mathrm{N}$, and $8.8 \%$ urea-N.

In Study I, QR and FL fertilizers were applied at a rate of 50 and $0.35 \mathrm{~g} \cdot \mathrm{m}^{-2}$, respectively 15 and $47 \mathrm{~d}$ after sod transplant (DAT), while SR was applied at a rate of $30 \mathrm{~g} \cdot \mathrm{m}^{-2} 15$ DAT. In Study II, QR and FL were applied at a rate of 50 and $0.35 \mathrm{~g} \cdot \mathrm{m}^{-2}$, respectively 6,41 , and 72 DAT, while SR was applied at a rate of 30 $\mathrm{g} \cdot \mathrm{m}^{-2}, 6$ and 72 DAT. In Study I, a third fertilizer application scheduled for 75 to 80 DAT could not be performed due to the frozen ground and the subsequent snow cover. The recommended application rates of each fertilizer type were used and the $\mathrm{N}$-amount for QR and SR was similar over a period of 2 months, which is the period of SR action (6.3 and $8.1 \mathrm{~g} \cdot \mathrm{m}^{-2}$ for $\mathrm{QR}$ and SR fertilizer, respectively). Due to the substantially different absorption mode of FL fertilization, the recommended rate was used to avoid phytotoxicity.

In each study, the parameters that were monitored included 1) the growth rate of the sward, 2) the visual quality of the sod, 3 ) the growth rate of the root system, 4) the anchorage rate of the sod, and 5) soil moisture content. The growth rate of the sod sward was determined as the weight of clippings collected by mowing at $55 \mathrm{~mm}$ at approximately weekly intervals, following drying at $75^{\circ} \mathrm{C}$ for $24 \mathrm{~h}$. Visual quality ratings of the sod were assessed on a 1 to 9 scale $(1=$ dead, $9=$ ideal and $6.5=$ minimum acceptable turf quality) at 7 or $15 \mathrm{~d}$ intervals depending on the growth of the grasses. To determine root growth, one soil core was taken from the whole depth of the profile of each plot on each sampling date using a metal cylinder, $400 \mathrm{~mm}$ long with a $50 \mathrm{~mm}$ internal diameter. The substrate was washed off carefully and the roots were oven dried for $24 \mathrm{~h}$ at $75^{\circ} \mathrm{C}$ for dry weight determination. The anchorage rate of the sod was evaluated by determination of the vertical force required to detach a piece of sod (King and Beard, 1969). To quantify vertical detachment force, six rectangular frames (300 $\times 300 \mathrm{~mm}$ with a 5-mm stainless-steel mesh) were placed in each plot. The sod was cut and fitted into each frame. Vertical force measurements were taken 10, 25, 36, 44, 57, $107 \mathrm{~d}$ and $19,31,44,57,69,93 \mathrm{~d}$ after sod transplant in Study I and Study II, respectively. On each date, a single frame was pulled by a pulley and winch until it detached from the substrate. The force required to detach a frame from the substrate was monitored by an S type load cell (LC101, Omega Engineering Limited, Manchester,U.K.) connected to a digital indicator(DP41-S, Omega Engineering Limited). During vertical force application, the highest reading until the detachment of the sod from the substrate was recorded and the weight of the frame with the detached sod was subtracted to obtain the net vertical detachment force of the sod. The moisture of the substrate was also recorded at the time of vertical force determination by removing intact soil cores, $50 \mathrm{~mm}$ in diameter and $280 \mathrm{~mm}$ in length, adjacent to each detached frame.

At the initiation and termination of the study $\mathrm{pH}$, electrical conductivity (EC), available $\mathrm{P}$

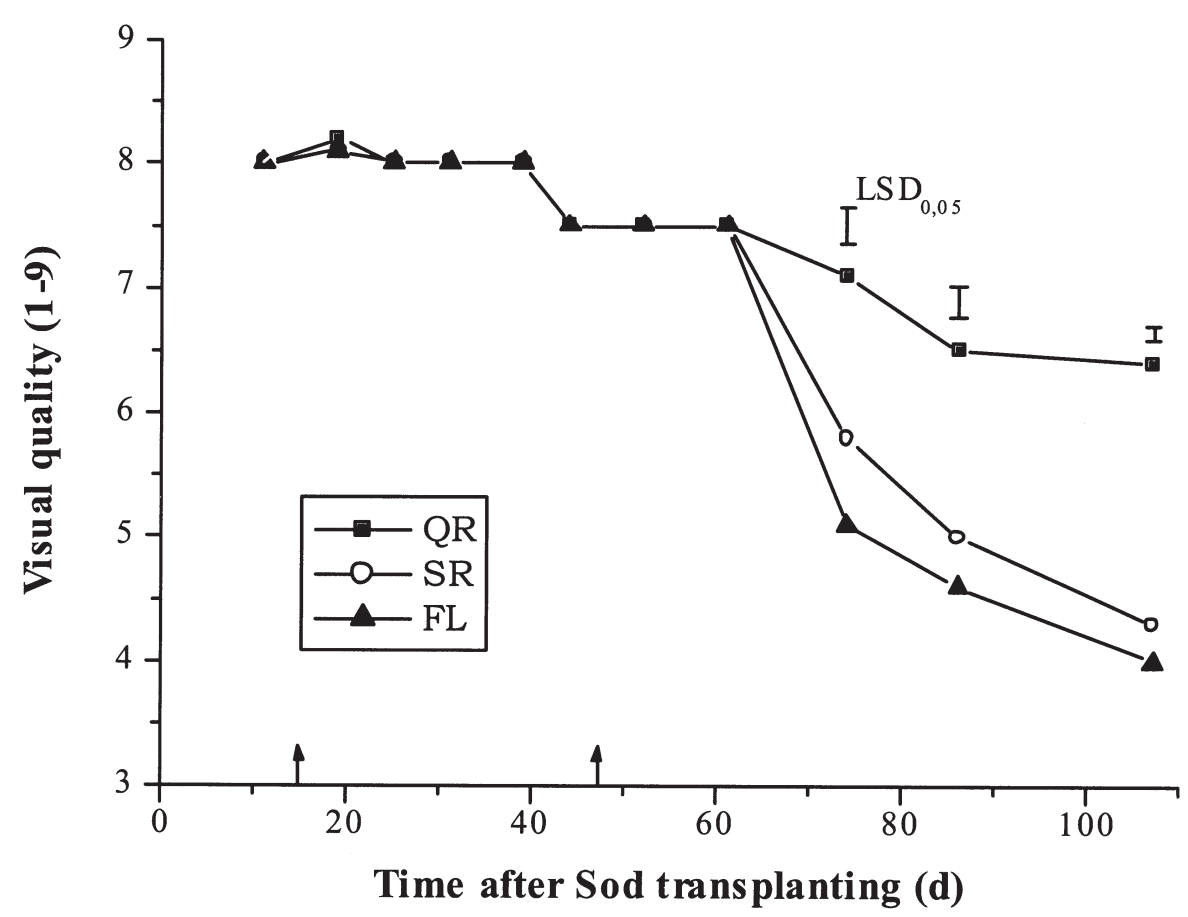

Fig. 1. Visual quality ratings $(1=$ dead, $9=$ ideal and $6.5=$ minimum acceptable turf quality $)$ as affected by fertilizer program during Study I $(\mathrm{QR}=$ quick release fertilizer; $\mathrm{SR}=$ slow release fertilizer; $\mathrm{FL}=$ foliar fertilizer). Values are the means of six replications. Bars represent the least significant difference (LSD) when treatment means are significantly different at a probability level $P \leq 0.05$. Arrows $(\uparrow)$ indicate the application dates of the fertilizer treatments. and exchangeable $\mathrm{K}, \mathrm{Ca}, \mathrm{Mg}$, and $\mathrm{Fe}$ were was determined colorimetrically using a spectrophotometer (Hitachi U2001) according to Olsen et al. (1954). Exchangeable cations (Ca, $\mathrm{Mg}$, and $\mathrm{K}$ ) and Fe were determined by atomic absorption spectrophotometry (GBC $932 \mathrm{~A} / \mathrm{A}$ ) with hollow cathode lamps in an air-acetylene flame. For $\mathrm{Ca}$ and $\mathrm{Mg}$ determinations, $\mathrm{La}_{2} \mathrm{O}_{3}$ was added to both the standard and diluted samples to achieve a concentration of 4,500 $\mathrm{mg} \cdot \mathrm{L}^{-1} \mathrm{La}$. Exchangeable $\mathrm{K}, \mathrm{Ca}$, and $\mathrm{Mg}$ were determined in the leachate after diluting with $1 \mathrm{M}$ ammonium acetate solution (Summer and Miller, 1996), while Fe was determined in the leachate by DTPA extraction solution (Lindsay and Norvell, 1978).

The experimental design for both studies was a $3 \times 2$ factorial (three fertilizer programs with and without UFRF) arranged in a randomised complete block design with 6 blocks. The analysis of variance was performed using Statgraphics Plus statistical software (Statistical Graphics Corp., Englewood Cliffs, N.J.) and treatment means were compared using the least significant difference(LSD) at a probability level $P \leq 0.05$.

\section{Results and Discussion}

Visual quality. In Study I, visual quality of the sod was high for the first $61 \mathrm{~d}$ after sod transplant (DAT) irrespective of treatment. At the end of the study, the low temperatures of the winter caused a reduction in sod visual quality, which was more pronounced in FL and SR fertilizer programs than QR (Fig. 1). This finding is similar to that observed by Powell (1977), Reeves et al. (1970), and Goatley et al. determined for each treatment. Phosphorus 
(1994), who reported that late-season N applications using quick release fertilizers prolonged the period of acceptable turf colour. In Study II, visual quality was similar for all fertilizer treatments and remained high $(>6.5)$ throughout the study. Differences in visual quality between UFRF amended and nonamended substrates on three sampling dates (Fig. 2) were minor. In both studies visual quality was not influenced by UFRF amendment or by interaction with the fertilization programs (data not shown).

Clipping yield. There was a slightly higher overall clipping yield in Study II (Fig. 3 and 4), which was performed in warmer climatic conditions, as observed by others (Baker and Jung, 1968; Peacock, 1975). In both studies,

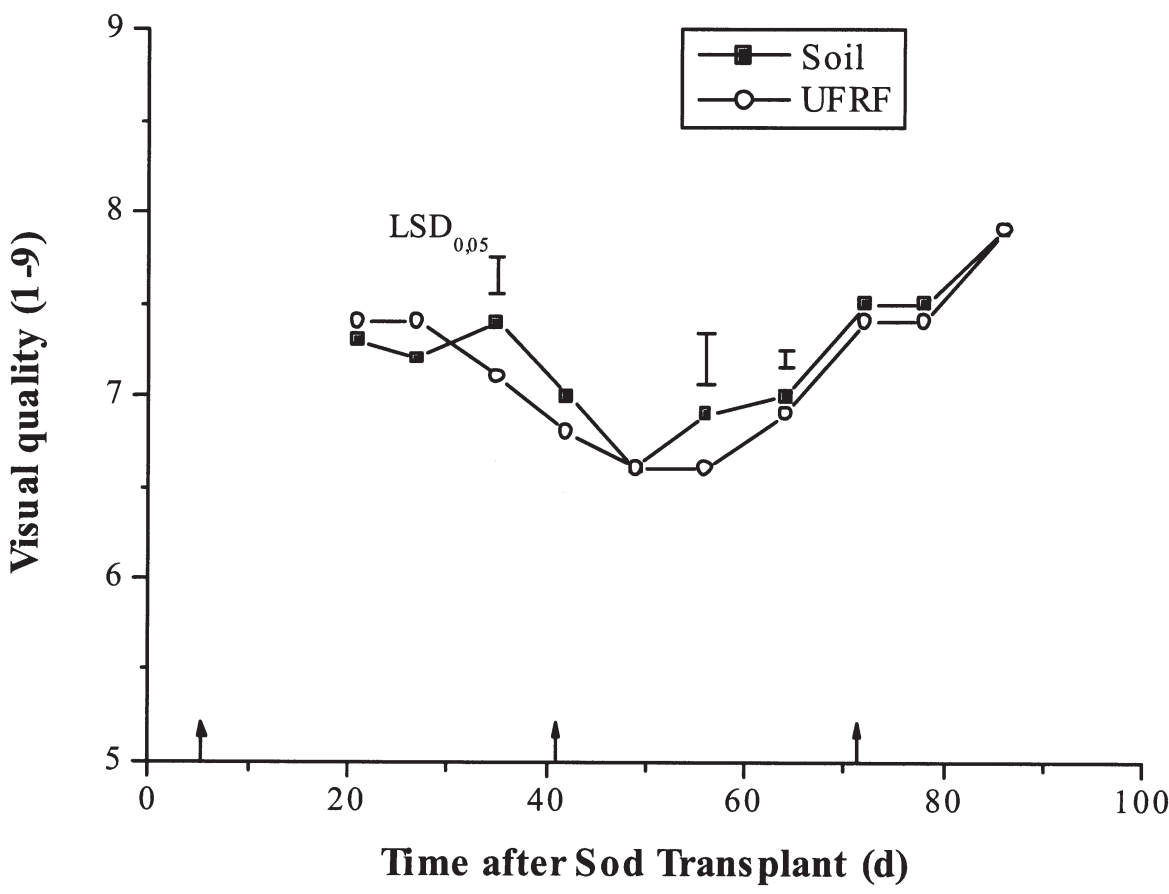

Fig. 2. Visual quality ratings $(1=$ dead, $9=$ ideal and $6.5=$ minimum acceptable turf quality $)$ as affected by UFRF amendment during Study II $(\mathrm{QR}=$ quick release fertilizer; $\mathrm{SR}=$ slow release fertilizer; FL $=$ foliar fertilizer). Values are the means of six replications. Bars represent the least significant difference (LSD) when treatment means are significantly different at a probability level $P \leq 0.05$. Arrows $(\uparrow)$ indicate the application dates of the fertilizer treatments.

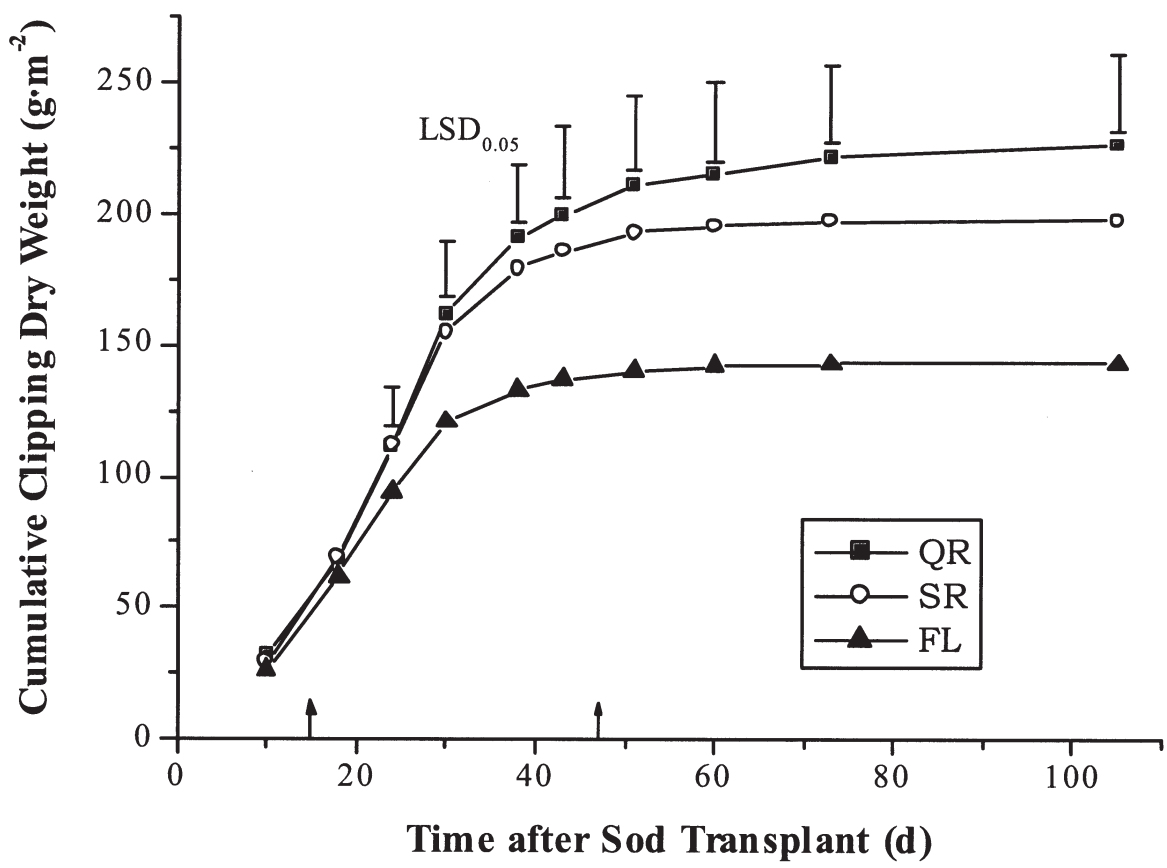

Fig. 3. Cumulative clipping yield $\left(\mathrm{g} \cdot \mathrm{m}^{-2}\right)$ as affected by fertilizer program during Study $I(Q R=$ quick release fertilizer; $\mathrm{SR}=$ slow release fertilizer; $\mathrm{FL}=$ foliar fertilizer). Values are the means of six replications. Bars represent the least significant difference (LSD) when treatment means are significantly different at a probability level $P \leq 0.05$. Arrows $(\uparrow)$ indicate the application dates of the fertilizer treatments.

the clipping yields were affected by fertilization type, but not by the UFRF amendment (data not shown). In Study I, the cumulative clipping yield (Fig. 3) increased until 30 DAT and then decreased due to the reduction of air temperature below $10{ }^{\circ} \mathrm{C}$. From 24 DAT, FL fertilizer resulted in lower clipping yields compared to QR and SR fertilizers. The differences observed between the FL fertilizer program compared with QR and SR were most likely due to the lower N (Watschke and Waddington, 1974) of the FL fertilizer program.

In Study II, clipping yields of all treatments were high on the first sampling date, but the growth rate of the sward declined thereafter due to the high summer temperatures (Fig. 4). As in Study I, FL fertilizer resulted in lower clipping yields than QR or SR. The delayed response of the 2nd QR fertilizer application was caused by a reduction in irrigation to prevent the spread of diseases.

Root dry weight. The influence of the fertilizer program and UFRF amendment on root dry weight was not consistent. However differences were apparent between particular sampling dates, and in both studies root growth was positively influenced by FL fertilization and negatively by UFRF amendment (Table 1).

In Study I, the beneficial effect of FL fertilization on sod rooting was evident at the 2 nd sampling date, 25 DAT. The effectiveness of FL fertilization at this stage could be attributed to the fact that the sod had most of its root system removed and consequently the absorption of the nutrients released by QR and SR fertilizers would be limited. However, comparing the results of the clipping yields, it was obvious that the nutrients provided by QR and SR were absorbed by the plants and promoted shoot growth (Fig. 3 and 4). The improved rooting response of FL fertilization could alternatively be attributed to a better absorption of $\mathrm{P}$ through foliar application since, it is well established that P promotes root growth (Juska et al., 1965; Powell, 1977) but is tightly retained by the soil particles and is not readily available to the plants. In such a case, the foliar application might have resulted in better Puptake by the plants, inducing prolific root growth. Another explanation might be that FL treatment produced low clipping yield (Fig. 3 and 4) and therefore, nutrient and carbohydrate removal by the clippings were minimal. These savings of plant energy might have increased carbohydrate accumulation and contributed to the improvement of root growth (Beard, 1973).

At the 4th and 6th sampling dates of Study I, the nonamended plots provided higher root dry weight than the UFRF amended ones (Table 1). It was also observed that root growth in all UFRF amended plots was reduced between the 3rd and 4th sampling dates, whereas root production in nonamended substrates was either increased or remained stable.

In Study II, root growth was seriously restricted by the high temperatures of the summer and reached a maximum value of $56 \mathrm{~g} \cdot \mathrm{m}^{-2} 57$ DAT, while in Study I, the maximum value was two and half time larger (Table 1). The FL treatment resulted in the highest root production on two out of the six sampling dates (4th and 6th). 


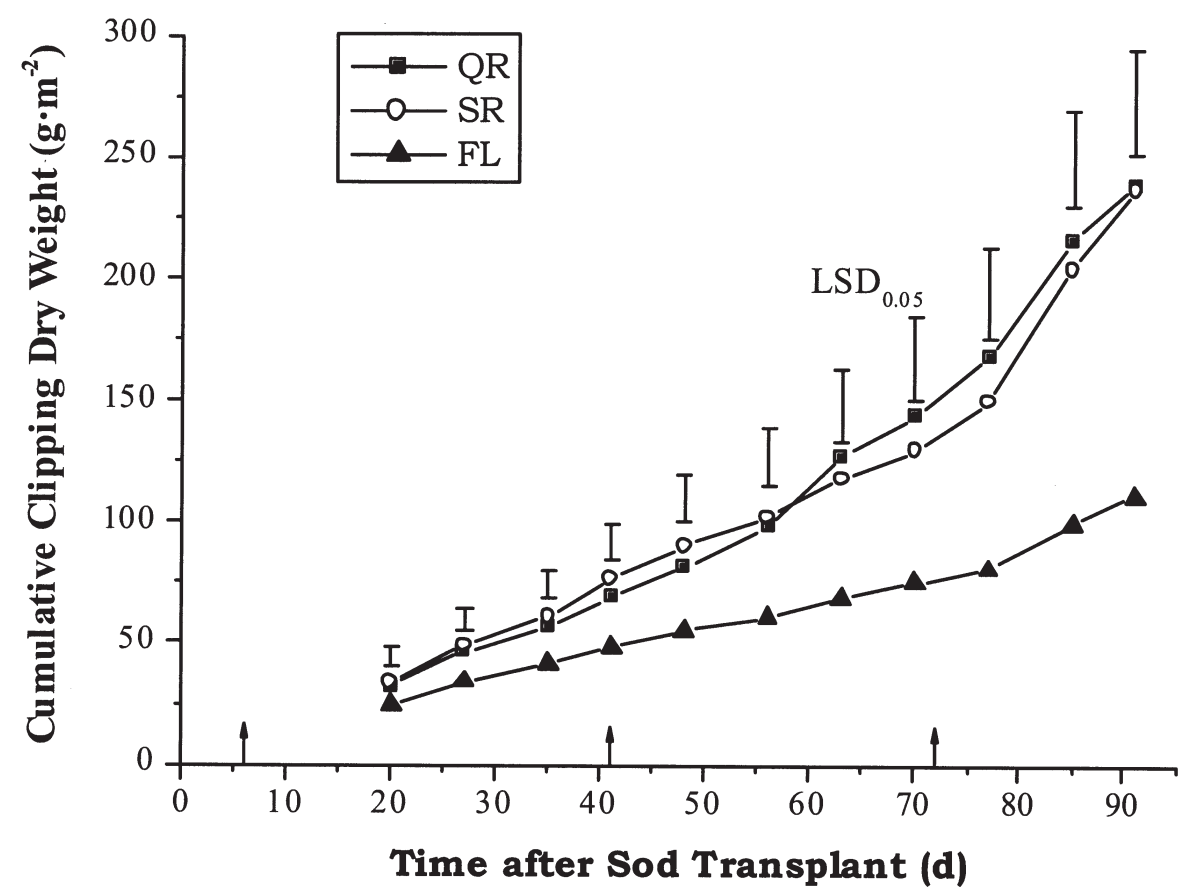

Fig. 4. Cumulative clipping yield $\left(\mathrm{g} \cdot \mathrm{m}^{-2}\right)$ as affected by fertilizer program during Study II $(\mathrm{QR}=$ quick release fertilizer; $\mathrm{SR}=$ slow release fertilizer; $\mathrm{FL}=$ foliar fertilizer). Values are the means of six replications. Bars represent the least significant difference (LSD) when treatment means are significantly different at a probability level $P \leq 0.05$. Arrows $(\uparrow)$ indicate the application dates of the fertilizer treatments.

Root growth from the 5 th to the 6th sampling date was significantly reduced in all treatments due to the increase of top growth (Fig. 4), which is known to deplete root carbohydrates and result in a reduction in root dry weight (Watschke and Waddington, 1975).

Vertical force. In Study I the vertical force required to detach a piece of sod was influenced by the type of fertilizer but not by UFRF amendment (data not shown). FL fertilization exhibited a clear advantage and required significantly more vertical force compared to the coefficient was 0.35 ).

Even though root dry weight was different between Studies I and II (Table 1), the vertical force required to detach the sod was similar(Table 2). In both studies, the vertical force of $5 \mathrm{kPa}$, which is considered to be the threshold value for sufficient sod anchorage (Peacock and Dudeck, 1985), was obtained within the first 20 to $25 \mathrm{~d}$, which could be the minimum time for sod establishment under Greek climatic conditions.

Soil nutrients. Differences in soil P, K, Ca, $\mathrm{Mg}$, and $\mathrm{Fe}$ concentrations between the treatments and the studies were inconsistent, except for K final concentrations, which were higher for QR fertilization in both studies compared to the other fertilization treatments. More specifically, at the final measurement of Study I, K concentration increased in nonamended profiles, while it was high in QR, moderate in SR, and low in FL fertilization (Table 3 ). The observed differences between fertilization treatments were probably caused by the different amounts of $\mathrm{K}$ applied with each fertilization program $\left(7.05 \mathrm{~g} \cdot \mathrm{m}^{-2}\right.$ for $\mathrm{QR}, 1.74 \mathrm{~g} \cdot \mathrm{m}^{-2}$ for $\mathrm{SR}$, and $0.058 \mathrm{~g} \cdot \mathrm{m}^{-2}$ for $\mathrm{FL}$ fertilization, respectively). Similar results were also observed for the final $\mathrm{K}$ concentration in Study II. The initial and final concentration of $\mathrm{K}$ was within the optimum range, while $\mathrm{Mg}$ and Ca concentrations were slightly above optimal level considering a soil CEC of 6.23. In contrast, $\mathrm{P}$ concentration was low in all cases according to Christians (1998).

Calcium concentration was reduced with QR fertilization at the final measurement of Study I, indicating that $\mathrm{S}$ contained within the QR fertilization $\left(4 \mathrm{~g} \cdot \mathrm{m}^{-2}\right.$ compared with none in the other fertilization treatments) might have reacted with and reduced the Ca concentration. A similar reduction of $\mathrm{Ca}$ concentration was observed at the initiation and termination of Study II for UFRF amended profiles. In this case, it is probable that the existence of $\mathrm{H}_{2} \mathrm{PO}_{4}$ and $\mathrm{SO}_{4}$ within the foam, promoted $\mathrm{Ca}$ pre-

Table 1. Root dry weight as affected by fertilizer program and UFRF amendment during Study I and II (QR = quick release fertilizer; SR = slow release fertilizer; $\mathrm{FL}=$ foliar fertilizer).

\begin{tabular}{|c|c|c|c|c|c|c|c|c|c|c|c|c|}
\hline \multirow[b]{4}{*}{ Treatment $^{2}$} & \multicolumn{12}{|c|}{ Root dry wt $\left(\mathrm{g} \cdot \mathrm{m}^{-2}\right)$} \\
\hline & \multicolumn{12}{|c|}{ Days after sod transplant } \\
\hline & \multicolumn{5}{|c|}{ Study I } & \multicolumn{7}{|c|}{ Study II } \\
\hline & 10 & 25 & 36 & 44 & 57 & 107 & 19 & 31 & 44 & 57 & 69 & 93 \\
\hline Nonamended & $5.24 \mathrm{a}$ & $44.41 \mathrm{a}$ & $70.07 \mathrm{a}$ & $82.57 \mathrm{a}$ & $93.67 \mathrm{a}$ & $149.35 \mathrm{a}$ & $20.83 \mathrm{a}$ & $36.58 \mathrm{a}$ & $41.36 \mathrm{a}$ & $43.33 \mathrm{a}$ & $52.13 \mathrm{a}$ & $33.33 \mathrm{a}$ \\
\hline UFRF amended & $7.35 \mathrm{a}$ & $39.12 \mathrm{a}$ & $65.82 \mathrm{a}$ & $57.90 \mathrm{~b}$ & $77.48 \mathrm{a}$ & $109.77 \mathrm{~b}$ & $18.53 \mathrm{a}$ & $24.88 \mathrm{~b}$ & $44.59 \mathrm{a}$ & $41.61 \mathrm{a}$ & $46.60 \mathrm{a}$ & $26.28 \mathrm{a}$ \\
\hline \multicolumn{13}{|l|}{ Fertilizer program $(\mathrm{Fr})$} \\
\hline
\end{tabular}

${ }^{\mathrm{z}}$ Within each treatment, means followed by the same letter are not significantly different $(P \leq 0.05)$.

Table 2. Sod vertical detachment force as affected by fertilizer type during Study I and II $(\mathrm{QR}=$ quick release fertilizer; $\mathrm{SR}=$ slow release fertilizer; FL $=$ foliar fertilizer).

\begin{tabular}{|c|c|c|c|c|c|c|c|c|c|c|c|c|}
\hline \multirow[b]{3}{*}{ Treatment ${ }^{2}$} & \multicolumn{12}{|c|}{ Vertical detachment force $(\mathrm{kPa})$} \\
\hline & \multicolumn{12}{|c|}{ Days after sod transplant } \\
\hline & 10 & 25 & 36 & 44 & 57 & 107 & 19 & 31 & 44 & 57 & 69 & 93 \\
\hline QR & $2.17 \mathrm{a}$ & $5.31 \mathrm{~b}$ & $6.66 \mathrm{~b}$ & $6.43 \mathrm{~b}$ & $6.78 \mathrm{a}$ & $10.84 \mathrm{a}$ & $3.84 \mathrm{a}$ & $6.82 \mathrm{a}$ & $5.87 \mathrm{a}$ & $6.77 \mathrm{a}$ & $8.29 \mathrm{a}$ & $8.34 \mathrm{a}$ \\
\hline SR & $1.86 \mathrm{a}$ & $5.55 \mathrm{~b}$ & $6.38 \mathrm{~b}$ & $6.79 \mathrm{~b}$ & $7.30 \mathrm{a}$ & $10.98 \mathrm{a}$ & $4.09 \mathrm{a}$ & $6.90 \mathrm{a}$ & $6.01 \mathrm{a}$ & $7.84 \mathrm{a}$ & $9.88 \mathrm{a}$ & $8.80 \mathrm{a}$ \\
\hline FL & $2.06 \mathrm{a}$ & $6.55 \mathrm{a}$ & $8.07 \mathrm{a}$ & $8.27 \mathrm{a}$ & $7.08 \mathrm{a}$ & $11.85 \mathrm{a}$ & $4.24 \mathrm{a}$ & $7.42 \mathrm{a}$ & $6.65 \mathrm{a}$ & $8.24 \mathrm{a}$ & $9.83 \mathrm{a}$ & $8.30 \mathrm{a}$ \\
\hline
\end{tabular}

${ }^{2}$ Within each treatment, means followed by the same letter are not significantly different $(P \leq 0.05)$. 
Table 3. Soil nutrient level ( $\mathrm{P}, \mathrm{K}, \mathrm{Ca}, \mathrm{Mg}, \mathrm{Fe})$ as affected by fertilizer program and UFRF amendment at the initiation and termination of Study I (QR $=$ quick release fertilizer; $\mathrm{SR}=$ slow release fertilizer; $\mathrm{FL}=$ foliar fertilizer).

\begin{tabular}{|c|c|c|c|c|c|c|c|c|c|c|}
\hline \multirow{2}{*}{ Treatment $^{2}$} & \multicolumn{10}{|c|}{ Nutrient level $\left(\mathrm{mg} \cdot \mathrm{kg}^{-1}\right)$} \\
\hline & \multicolumn{5}{|c|}{ Initial } & \multicolumn{5}{|c|}{ Final } \\
\hline \multicolumn{11}{|l|}{ Substrate (Sb) } \\
\hline UFRF amended & $6.28 \mathrm{a}$ & $93.7 \mathrm{a}$ & $1,391 \mathrm{a}$ & $198 \mathrm{a}$ & $4.69 \mathrm{a}$ & $9.14 \mathrm{a}$ & $78.7 \mathrm{~b}$ & $1,091 \mathrm{a}$ & $120 \mathrm{~b}$ & $4.55 \mathrm{a}$ \\
\hline \multicolumn{11}{|c|}{ Fertilizer program $(\mathrm{Fr})$} \\
\hline $\mathrm{QR}$ & $6.68 \mathrm{a}$ & $100.8 \mathrm{a}$ & $1,378 \mathrm{a}$ & $211 \mathrm{a}$ & $4.97 \mathrm{a}$ & $7.45 \mathrm{a}$ & $90.0 \mathrm{a}$ & $972 \mathrm{~b}$ & $143 \mathrm{a}$ & $4.43 \mathrm{a}$ \\
\hline SR & $5.03 \mathrm{a}$ & $89.0 \mathrm{a}$ & $1,366 \mathrm{a}$ & $170 \mathrm{a}$ & $3.67 \mathrm{a}$ & $6.62 \mathrm{a}$ & $85.0 \mathrm{ab}$ & $1,163 \mathrm{a}$ & $149 \mathrm{a}$ & $5.56 \mathrm{a}$ \\
\hline
\end{tabular}

${ }^{2}$ Within each treatment, means followed by the same letter are not significantly different $(P \leq 0.05)$.

$\mathrm{NS},, * * *^{* *}$ Nonsignificant or significant at the 0.05 or 0.01 level, respectively.

Table 4. Soil nutrient level ( $\mathrm{P}, \mathrm{K}, \mathrm{Ca}, \mathrm{Mg}, \mathrm{Fe})$ as affected by fertilizer program and UFRF amendment at the initiation and termination of Study II (QR = quick release fertilizer; $\mathrm{SR}=$ slow release fertilizer; $\mathrm{FL}=$ foliar fertilizer).

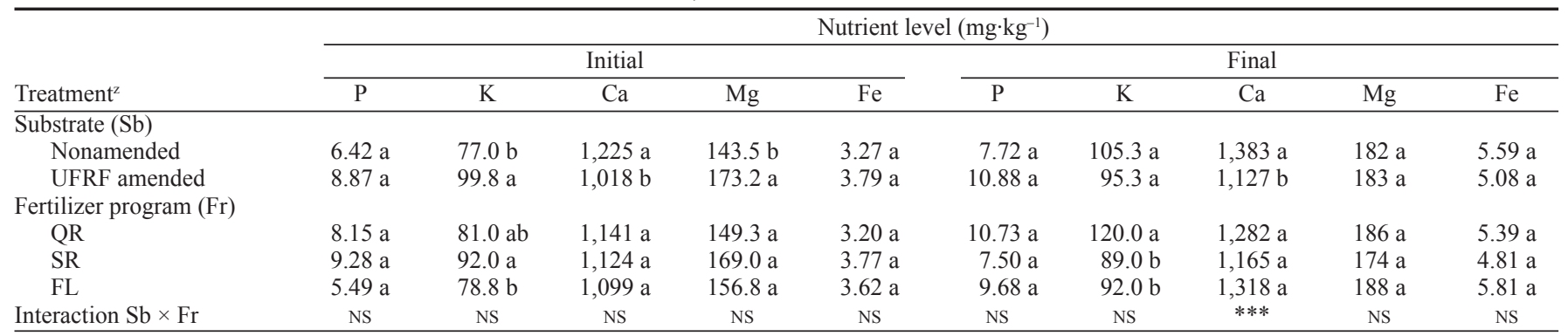

${ }^{2}$ Within each treatment, means followed by the same letter are not significantly different $(P \leq 0.05)$.

${ }_{\mathrm{NS}, * * *}^{* *}$ Nonsignificant or significant at the 0.001 level, respectively

cipitation. Similar trends were also observed for UFRF amended profiles in Study I, but the differences were not significant. Despite the reduction in $\mathrm{Ca}$ concentration, $\mathrm{pH}$ and $\mathrm{EC}$ values remained unchanged throughout both studies (Table 2).

In conclusion, foliar fertilization should be utilized for sod establishment since it can enhance and accelerate sod anchorage and root growth. Quick release fertilizers have negative effects on sod root growth and establishment but their use in late autumn can improve winter green up of the sod and visual quality. Slow release fertilizers provide moderate shoot growth but do not enhance root growth of the sod. UFRF did not improve or accelerate sod establishment in either study. It is also evident that UFRF possesses a minimal capacity to improve soil properties and offers only a limited benefit to sandy loam soils.

\section{Literature Cited}

Baader, P. 1999. Fytogreen-foam in laying out sport fields. 1st Fytogreen Seminar, 2-3 Dec., Beneden Leeuwen, The Netherlands.

Baker, B.S. and G.A. Jung. 1968. Effect of environmental conditions on the growth of four perennial grasses. I. Response to controlled temperature. Agron. J. 60:155-158.

Beard, J.B. 1973. Turfgrass science and culture. Prentice-Hall, Inc., Englewood Cliffs, N.J.

Bingaman, B.R., N.E. Christians, and D.S. Gardner. 2001. Trinexapac-ethyl effects on rooting of kentucky bluegrass (Poa pratensis) sod. Int. Turfgrass Soc. Res. J. 9:832-834

Bowman,D.C. and J.L.Paul. 1992. Foliar absorption of urea, ammonium, and nitrate by perennial ryegrass turf. J. Amer. Soc. Hort. Sci. 117:75-79.

Christians, N.E. 1998. Fundamentals of turfgrass management. Ann Arbor Press, Chelsea, Mich.
Cisar, J.L., G.H. Snyder, and G.S. Swanson. 1992. Nitrogen, phosphorus and potassium fertilization for histosol-grown st. augustinegrass Sod. Agron. J. 84:475-479.

Dunn, J.H. and R.E. Engel. 1970. Rooting ability of Merion kentucky bluegrass sod grown on mineral and muck soil. Agron. J. 62:517-520.

Goatley, J.M., V. Maddox, D.J. Lang, and K.K. Crouse. 1994. 'Tifgreen' bermudagrass response to lateseason application of nitrogen and potassium. Agron. J. 86:7-10.

Huang, B., X. Liu, and J.D. Fry. 1998. Effects of high temperature and poor soil aeration on root growth and viability of creeping bentgrass. Crop Sci. 38:1618-1622.

Juska, F.V., A.A. Hanson, and C.J. Erickson. 1965. Effects of phosphorus and other treatments on the development of red fescue, Merion and common kentucky bluegrass. Agron. J. 57:75-78.

King, J.W. and J.B. Beard. 1969. Measuring rooting of sodded turfs. Agron. J. 61:497-498.

King, J.W. and J.B. Beard. 1972. Postharvest cultural practices affecting rooting of kentucky bluegrass sods grown on organic and mineral soils. Agron. J. 64:259-262.

Lindsay, W.L. and W.A.Norvell. 1978. Development of a DTPA test for zinc, iron, manganese and copper. Soil Sci. Soc. Amer. J. 42:421-428.

Mooney, S. and S. Baker. 1999. The effects of phytogreen foam on the soil physical properties of sanddominated rootzones for sports turf. A laboratory study. Sports Turf Res. Inst. (STRI) Do. 0066/3.

Nektarios,P.A.,A.-E. Nikolopoulou, and I.Chronopoulos. 2003. Sod establishment and turfgrass growth as affected by urea-formaldehyde resin foam soil amendment. Scientia Hort. 100:203-213.

Olsen, S.R., C.V. Cole, F.S. Watanabe, and L.A. Dean. 1954. Estimation of available phosphorus in soils by extraction with sodium bicarbonate. U.S. Dept. Agr. Circ. 939.

Peacock, C.H. and A.E. Dudeck. 1985. A comparison of sod type and fertilization during turf establishment. HortScience 20:108-109.
Peacock, J.M. 1975. Temperature and leaf growth in Lolium perenne. I. The thermal microclimate: Its measurement and relation to crop growth. J. Appl. Ecol. 12:99-114.

Powell, C.L. 1977. Effect of phosphate fertilizer and plant density on phosphate inflow into ryegrass roots in soil. Plant and Soil. 47:383-393.

Reeves, S.A., G.G. McBee, and M.E. Bloodworth. 1970. Effect of N, P, and K tissue levels and late fall fertilization on the cold hardiness of Tifgreen bermudagrass (Cynodon dactylon $\times$ Cynodon transvaalensis). Agron. J. 62:659-662.

Rodriguez, I.R., G.I. Miller, and L.B. McCarty. 2001. Bermudagrass establishment on high sand-content soils using various $\mathrm{N}-\mathrm{P}-\mathrm{K}$ ratios. HortScience 37:208-209.

Schmidt, R.E., R.H. White, and S.W. Bingham. 1986. Technique to measure rooting of sods grown in small containers. Agron. J. 78: 212-216.

Snyder, G.H. and J.L.Cisar. 2000. Nitrogen/Potassium fertilization ratios for Bermudagrass turf. Crop Sci. 40:1719-1723.

Summer, M.E. and W.P. Miller. 1996. Cation exchange capacity and exchange coefficients. In: D.L. Sparks (ed.). Methods of soil analysis. Part 2: Chemical properties. 3rd ed. ASA-SSSA-CSSA, Madison, Wis.

Theoharopoulos, S.P. 1992. Soil study of Biotias prefecture. Mapping, processing, evaluation of soils in Biotia. (in Greek). Natl. Agr. Res. Found.

Watschke, T.L. and D.V. Waddington. 1974. Effect of nitrogen source, rate, and timing on growth and carbohydrates of 'Merion' kentucky bluegrass. Agron. J. 66:691-696.

Watschke, T.L. and D.V. Waddington. 1975. Effect of nitrogen fertilization on the recovery of 'Merion' kentucky bluegrass from scalping and wilting. Agron. J. 67:559-563.

Werminghausen, B. 1972. The application of synthetic media in plant propagation. III Symposium on Peat in Horticulture, Dublin Ireland. Acta Hort. 26:159-64. 